\title{
ORIGINAL ARTICLE \\ Can resource costs of polyploidy provide an advantage to sex?
}

\begin{abstract}
M Neiman ${ }^{1}, \mathrm{AD} \mathrm{Kay}^{2}$ and AC Krist ${ }^{3}$
The predominance of sexual reproduction despite its costs indicates that sex provides substantial benefits, which are usually thought to derive from the direct genetic consequences of recombination and syngamy. While genetic benefits of sex are certainly important, sexual and asexual individuals, lineages, or populations may also differ in physiological and life history traits that could influence outcomes of competition between sexuals and asexuals across environmental gradients. Here, we address possible phenotypic costs of a very common correlate of asexuality, polyploidy. We suggest that polyploidy could confer resource costs related to the dietary phosphorus demands of nucleic acid production; such costs could facilitate the persistence of sex in situations where asexual taxa are of higher ploidy level and phosphorus availability limits important traits like growth and reproduction. We outline predictions regarding the distribution of diploid sexual and polyploid asexual taxa across biogeochemical gradients and provide suggestions for study systems and empirical approaches for testing elements of our hypothesis.
\end{abstract}

Heredity (2013) 110, 152-159; doi:10.1038/hdy.2012.78; published online 28 November 2012

Keywords: sexual reproduction; ploidy; phosphorus; parthenogenesis; ecological stoichiometry; nutrient

\section{INTRODUCTION}

All else being equal, asexual females will produce twice as many daughters as sexual females, which make both male and female offspring. Because only females contribute directly to the rate of population growth, the production of males creates a twofold cost of sexual reproduction that should theoretically result in the selective elimination of sex (Maynard Smith, 1978). Why sex remains so common despite this and other costs has been termed the 'queen of questions' in evolutionary biology (Bell, 1982; recently reviewed in Meirmans et al., 2012) and continues to be the focus of much theoretical and empirical research (Otto, 2009; Zimmer, 2009).

Costs of sex can be mitigated if sex confers advantages. Most often, research aimed at identifying the advantages of sex has focused on hypotheses invoking direct benefits of recombination such as disrupting linkage disequilibria, clearing deleterious mutations, and/or producing genetically variable offspring. Although recombinationfocused hypotheses have received considerable support, it is likely that no single hypothesis will provide a general explanation for the persistence of sex in natural populations. Instead, there is a growing sense that the maintenance of sex may often rely on complex or multiple mechanisms involving ecological variables (Butlin et al., 1999; West et al., 1999; Meirmans and Neiman, 2006; Scheu and Drossel, 2007; Otto, 2009; Zimmer, 2009; Meirmans et al., 2012).

Resource availability is a well-known mediator of species interactions that has been incorporated into models of the evolution and maintenance of sex. Most notably, the 'Tangled Bank' hypothesis (Bell, 1982, p. 131) predicts that resource competition can favor sex if offspring with distinct genotypes (for example, those produced by sex) are better at competing for limited food resources than asexually produced copies of existing genotypes (Maynard Smith, 1978; Young, 1981; Bell, 1982; Doncaster et al., 2000; recently reviewed in Song et al., 2011). Although the Tangled Bank has received less attention than other hypotheses for sex (for example, Red Queen, Muller's Ratchet), the ideas laid out in the Tangled Bank hypothesis provide an example of how resource interactions in principle could influence competitive dynamics between sexual and asexual taxa.

Here, we incorporate ideas from nutritional ecology to provide an alternative mechanism by which food resources could mitigate the inherent cost of sex. We focus on recent advances in nutrition research that point to the importance of interactions among food components (distinct biochemicals or elements) for organismal performance, and in particular on how dietary scarcities or excesses of particular components can favor organisms with particular traits (Sterner and Elser, 2002; Kay et al., 2005; Elser and Hamilton, 2007; Raubenheimer et al., 2009). We argue that a common difference between sexual and asexual taxa, ploidy level (Bierzychudek, 1985; Suomalainen et al., 1987; Otto and Whitton, 2000), may influence dietary nutrient demands and in turn competitive interactions between diploid sexual and polyploid asexual taxa across spatial and temporal gradients in nutrient availability. Our hypothesis is that higher ploidy increases demands for dietary phosphorus (P), an important component of nucleic acids, and thus that environmental $\mathrm{P}$ availability can mediate the relative success of sexual and asexual taxa that differ in ploidy level (Figure 1).

We begin by briefly reviewing the association between asexuality and polyploidy and bring together data suggesting that elevated ploidy will influence body composition. Next, we present the idea that higher ploidy will often be associated with higher demands for dietary

${ }^{1}$ Department of Biology, University of lowa, lowa City, IA, USA; ${ }^{2}$ Department of Biology, University of St Thomas, St Paul, MN, USA and ${ }^{3}$ Department of Zoology and Physiology and Program in Ecology, University of Wyoming, Laramie, WY, USA

Correspondence: Professor M Neiman, Department of Biology, University of lowa, lowa City, IA 52242, USA.

E-mail: maurine-neiman@uiowa.edu

Received 24 May 2012; revised 26 July 2012; accepted 1 August 2012; published online 28 November 2012 

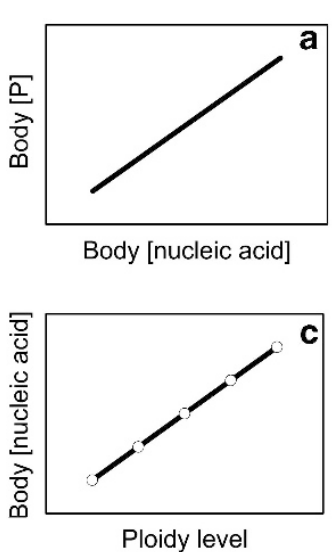
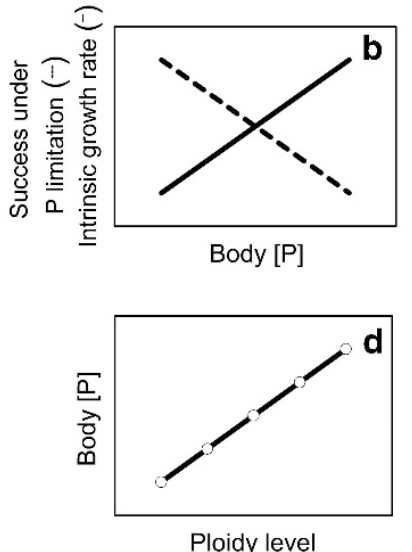

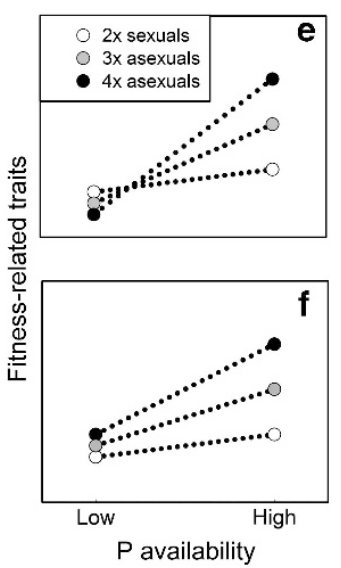

Figure1 A conceptual model of how nutrient limitation contributes to the maintenance of sex. (a) Variation in bodily $\mathrm{P}$ content is due to variation in nucleic acid content (Elser et al., 2003, 2006). (b) High P organisms have higher intrinsic growth rates (Elser et al., 1996, 2003), but may be more susceptible to P limitation (Sterner and Elser, 2002). (c) Taxa with higher ploidy have higher per-cell nucleic acid content; they may also have higher nucleic acid content per unit mass. (d) If taxa with higher ploidy have higher bodily nucleic acid content, they should also have higher bodily P content. (e) and (f) If (b) and (d) are true, success of asexual polyploids will vary more with environmental $P$ availability than will the success of sexual diploids. This greater sensitivity to $P$ availability may be sufficient on its own to maintain sex when $\mathrm{P}$ availability is low (e), or it may simply reduce the competitive advantage of asexuals (f).

P. We then develop the hypothesis that $\mathrm{P}$ availability could mediate interactions between sexual and asexual taxa differing in ploidy level, and we outline a series of predictions regarding the distribution of diploid sexual and polyploid asexual taxa as a function of environmental P availability. Finally, we describe a study system that we have used to test key elements of the hypothesis. We conclude with suggestions for empirical approaches to determine whether higher nutrient demands are imposed upon polyploid asexuals and whether these increased demands are substantial enough to be relevant for the maintenance of sex.

\section{A DISADVANTAGE OF POLYPLOIDY?}

Polyploidy is intimately associated with sex because asexual plants and animals are often of higher ploidy level than closely related sexual taxa (Bierzychudek, 1985; Suomalainen et al., 1987; Otto and Whitton, 2000; recently reviewed in Neiman and Schwander, 2011). Since ploidy-level variation can affect traits from gene expression to the rate of spread of beneficial mutations to immune function (reviewed in Otto and Whitton, 2000; Comai, 2005; Mable et al., 2011; King et al., 2012), it may be of relevance when considering the outcome of competition between sexual and asexual lineages that differ in ploidy.

Polyploidy is most often viewed as a positive trait, either by influencing the phenotype in a way that can provide fitness advantages (Levin, 1983; Gregory and Hebert, 1999; Otto and Whitton, 2000; Lundmark and Saura, 2006; Hegarty and Hiscock, 2008; te Beest et al., 2012), by facilitating adaptation via epigenetic or genomic remodeling immediately following ploidy elevation (largely in allopolyploids; Hegarty and Hiscock, 2007; Soltis et al., 2010; Albertin and Marullo, 2012; Buggs et al., 2012), or by providing 'extra' genomic material that can serve as raw material for evolutionary innovation (Ohno, 1970; Otto and Whitton, 2000; Parisod et al., 2010). Recent direct empirical support for positive phenotypic effects of polyploidy (Ramsey, 2011) and indirect evidence for a connection between polyploidy and the evolution of novel adaptations (recently reviewed in Flagel and Wendel, 2009; Parisod et al., 2010; Balao et al., 2011) support the view that polyploidy is often beneficial.
On the other hand, polyploidy may also confer costs (reviewed in Comai, 2005; Otto, 2007). For example, population genetic analyses suggest that the equilibrium load of harmful mutations will increase with ploidy level (Otto and Whitton, 2000; Otto and Gerstein, 2009). Data from a variety of plant and animal taxa also suggest that polyploid individuals generally develop more slowly than their diploid counterparts (Cavalier-Smith, 1978; Levin, 1983). Yet another potential cost of polyploidy was suggested by Lewis (1985), who argued that the metabolic cost and high nitrogen and phosphorus content of DNA meant that reduced ploidy level might be favored in nutrientpoor conditions because of reduced nutrient requirements.

In light of the frequent association of asexuality and polyploidy, we consider whether a nutrient limitation mechanism like that envisioned by Lewis (1985) might be relevant to understanding the distribution and maintenance of sexual diploid vs. asexual polyploid organisms.

\section{Ploidy, nucleic acids and whole-organism $P$ content}

The role of food resources is a focus of seminal theoretical texts on ecological interactions and adaptive evolution (MacArthur, 1972; Tilman, 1982; Grover, 1997; Chase and Leibold, 2003), but only recently have researchers begun to emphasize how the nutritional components of foods can interact to influence ecological and evolutionary outcomes. Two main frameworks-the Geometric Framework of Nutrition (Raubenheimer et al., 2009; Simpson and Raubenheimer, 2012), which focuses on biochemicals (mainly protein, carbohydrates and lipids), and Ecological Stoichiometry (Sterner and Elser, 2002), which focuses on ratios of elements (mainly carbon, nitrogen and phosphorus)-have been developed to explore the interactive effects of multiple dietary components on organism performance. Some areas of emphasis in this research are that (1) dietary nutritional imbalances provide distinct challenges for organisms depending on the nature of the imbalance (Kay et al., 2005) (2) scarcities of particular nutrients can affect trait expression in specific ways (Morehouse et al., 2010) and (3), the relative availability of nutrients can influence the nature and dynamics of competitive and other species interactions (Moe, 2005). 
One idea from this literature that may be relevant to understanding the distribution and maintenance of ploidy variation and sex is the role of phosphorus $(\mathrm{P})$ in organismal growth, labeled the growth rate hypothesis (Elser et al., 1996, 2003). The premise of the growth rate hypothesis is that nucleic acids contain $\sim 9 \% \mathrm{P}$ per unit dry mass, which is considerably higher than $\mathrm{P}$ levels in other biomolecules except phospholipids, ATP, ADP, AMP, and free nucleotides (Elser et al., 1996). However, unlike other P-containing biomolecules, nucleic acids can comprise a large, but variable, fraction of organismal dry mass (Sterner and Elser, 2002). As a result, allocation to nucleic acids likely accounts for much of the variation in whole-organism $\mathrm{P}$ concentration in a wide range of invertebrate taxa (Elser et al., 2003). The growth rate hypothesis predicts that increased allocation to P-rich ribosomal RNA is required to meet the protein synthesis demands of rapid growth and thus can account for the positive association between maximal growth rate and body $\mathrm{P}$ content in invertebrates (Elser et al., 2003). Consequently, increasing allocation to nucleic acids and thus body $\mathrm{P}$ content makes fitness gains more sensitive to scarcity of environmental P (Elser et al., 2000b, 2006).

The impact of dietary $\mathrm{P}$ and nucleic acid allocation on organism performance suggests a cost to polyploidy (Lewis, 1985), but this cost has not been considered in the context of the evolution of sex. If higher ploidy in animals is associated with higher whole-body $\mathrm{P}$ content and dietary requirements, then polyploid animals may be at a competitive disadvantage where environmental $\mathrm{P}$ availability is scarce. Given the frequent difference in ploidy level between asexual and sexual animals (Suomalainen et al., 1987; Otto and Whitton, 2000; Lundmark and Saura, 2006), this hypothesis suggests that P availability could mediate competitive interactions between polyploid asexual and diploid sexual taxa. This focus on a nutrient-based disadvantage of polyploidy is a novel way to consider why sex might be favored under some circumstances, implying that the 'paradox' of sex could be mitigated by the ecological costs of additional chromosome sets in asexual polyploids.

\section{Polyploidy and organismal phosphorus economics}

Higher ploidy is generally associated with increased nuclear DNA content (Leitch and Bennett, 2004; Cavalier-Smith, 2005; Gregory, 2001, 2005). This increased per-cell nuclear DNA content, however, does not necessarily translate into higher whole-organism $\mathrm{P}$ concentration. For one, polyploids often have larger (and fewer) cells (Fankhauser, 1945; Benfey, 1999; reviewed in Mable, 2004), and smaller haploid genomes (Ozkan et al., 2003; Leitch and Bennett, 2004; Murray et al., 2005; Gerstein et al., 2006; Eilam et al., 2010; Pellicer et al., 2010) relative to closely related taxa with lower ploidy. In addition, variation in RNA content may have more of an effect than variation in DNA content on body P content because RNA (1) makes up a substantial fraction of organismal biomass $(>15 \%$ dry mass in some animals and $>40 \%$ dry mass in bacteria; Elser et al., 1996, 2003) and (2) varies considerably among taxa (for example, \%RNA ranges from $<1 \%$ to $>13 \%$ dry mass in zooplankton (Gillooly et al., 2005)).

There is evidence for a positive relationship between ploidy level and allocation to nucleic acids from research on how ploidy affects gene expression. This question has been studied primarily in model plant systems (reviewed in Adams, 2007) and in yeast (Galitski et al., 1999; Pavelka et al., 2010) but has otherwise received little attention (Comai, 2005). While gene expression in polyploid plants is often regulated differently than in diploid progenitors (Adams and Wendel, 2005), this phenomenon is often due more to hybridization than to polyploidy per se (Levin, 1983; Albertin et al., 2006; Wang et al., 2006;
Adams, 2007; Stupar et al., 2007; Church and Spaulding, 2009; Ng et al., 2012). In fact, polyploidization usually does not substantially affect expression levels of individual gene copies, such that wholeorganism expression of a given gene product is most often a positive function of ploidy (Bachmann and Bogart, 1975; Guo et al., 1996; Galitski et al., 1999; reviewed in Wendel, 2000; Birchler et al., 2001; Auger et al., 2005; Stupar et al., 2007; Pignatta et al., 2010; Albertin and Marullo, 2012). Altogether, the outcomes of these studies on the relationship between ploidy and gene expression imply that wholeorganism RNA content should typically scale up with ploidy level, though this relationship remains to be well established in animals. In general, information is needed on whole-organism allocation to DNA and RNA in closely related taxa that differ in ploidy, as research on nucleic acids and ploidy has been focused primarily at the cellular and genetic level.

If body $\mathrm{P}$ content generally increases with ploidy, it is likely that ploidy differences will be associated with differences in sensitivity to environmental P scarcity. Stoichiometric models that combine information on energetics and body composition predict that body $\mathrm{P}$ content (and body carbon (C):P ratio) is an important determinant of sensitivity to P limitation (Frost et al., 2006; Shimizu and Urabe, 2008). This prediction has received some empirical support in both aquatic and terrestrial systems (Stelzer and Lamberti, 2002; Fagan and Denno, 2004; Frost et al., 2006; Shimizu and Urabe, 2008).

There is also evidence that scarcity of particular nutrients has influenced the evolution of body composition. For example, Elser et al. (2011) provide evidence that some variation in amino-acid composition among taxa reflects selection for efficient use of limited nutrients. Similarly, Hessen et al. (2010) suggest that genome streamlining could be favored under conditions of $\mathrm{P}$ scarcity, particularly if there is corresponding selection for rapid growth. These authors also suggest that demand for rapid maximal growth may have favored increased allocation of P to RNA instead of DNA production. Altogether, though we still only have a very limited understanding of how nutrient (and particularly P) limitation has influenced the evolution and maintenance of animal ploidy variation, the ideas involved are supported by existing theory and data and are well suited for testing with both lab- and field-based studies.

\section{CONSEQUENCES OF HIGH P CONTENT FOR ASEXUAL ECOLOGY}

If greater allocation to $\mathrm{P}$-rich materials increases dietary $\mathrm{P}$ requirements for asexual polyploids, it may mediate competitive interactions across environmental $\mathrm{P}$ gradients (Figure 1). Specifically, greater sensitivity to $\mathrm{P}$ availability in asexual polyploids may eliminate (Figure 1e) or at least diminish (Figure 1f) the sexuality and/or ploidy-related competitive advantage over diploid sexuals when $\mathrm{P}$ is limiting. As a result, sexual diploid animal taxa may be more likely to persist in environments where $\mathrm{P}$ is relatively scarce.

The idea that ploidy affects organismal ecology has a long history (Vandel, 1928; Stebbins, 1938; Suomalainen, 1950; Cavalier-Smith, 1978; Bell, 1982; Levin, 1983; Bierzychudek, 1985), but there is still no consensus on whether there are definitive advantages or costs of polyploidy that can explain its frequency and distribution (Mable and Otto, 1998; Mable, 2001; Ramsey and Schemske, 2002; Zeyl, 2004; Buggs and Pannell, 2007; Gerstein and Otto, 2009; Soltis et al., 2010; Beck et al., 2011; Mayrose et al., 2011; Ramsey, 2011). The advantages and disadvantages of polyploidy and its relevance to the distribution and maintenance of sex have been reviewed extensively (Bierzychudek, 1985; Suomalainen et al., 1987; Otto and Whitton, 
2000; Comai, 2005; Kearney, 2005; Lundmark and Saura, 2006), so we provide only a brief overview.

The ecological consequences of polyploidy are difficult to empirically disentangle from those directly related to asexuality, with which it is so often associated (Bierzychudek, 1985; Otto and Whitton, 2000; Hörandl, 2006; Mable et al., 2011). In a diverse array of plants and animals, asexual lineages (Vandel, 1940; Suomalainen, 1950; Ghiselin, 1974; Levin, 1975; Bell, 1982; Lynch, 1984; Law and Crespi, 2002; Hörandl, 2006) and polyploid taxa (Vandel, 1928; Bierzychudek, 1985; Beaton and Hebert, 1988; Kearney, 2005; Maniatsi et al., 2011) increase in abundance at higher latitudes or altitudes relative to their sexual and/or lower ploidy counterparts. Some authors have pointed to advantages and disadvantages of asexuality per se as an explanation for these different distributional patterns (Levin, 1975; Glesener and Tilman, 1978; Bell, 1982; Jensen et al., 2002; Frantz et al., 2006; Ben-Ami and Heller, 2007; Martins et al., 2008). However, several authors have instead suggested that polyploidy is a more likely explanation (Bierzychudek, 1985; Beaton and Hebert, 1988; Lundmark and Saura, 2006; Adolfsson et al., 2010). For example, Bierzychudek (1985) pointed out that asexuality was so frequently associated with polyploidy in plants that it was 'premature' to implicate sex as a causal factor for distributional differences between asexual and sexual plant taxa (also see Suomalainen et al., 1987). Instead, she proposed that the genetic advantages of polyploidy (for example, mutational buffering) might instead underlie the broad distribution of asexual relative to sexual forms.

This idea has found support from studies such as that of Stenberg et al. (2003), who contended that broad distribution of triploid vs. diploid asexual weevils suggested an intrinsic advantage of polyploidy (also see Adolfsson et al., 2010). More broadly, Stenberg et al. (2003) presented evidence for 'geographical polyploidy', a pattern analogous to geographical parthenogenesis, in which polyploid forms, regardless of sexuality, also tend to be found in higher latitudes (also see Suomalainen et al., 1987). They argued that this pattern suggests that ploidy plays a key role in determining the distribution of many sexual and asexual taxa.

Other perspectives are also common. For example, Kearney (2005) and Hörandl (2006) contend that polyploidy per se does not provide a sufficient explanation for distributional differences between sexual and asexual taxa. A similar conclusion is reached by a more recent paper exploring the geographic distribution of diploid sexual and diploid, triploid, and tetraploid asexual brine shrimp (Maniatsi et al., 2011). Kearney (2005) concluded that hybridization may be a more important contributor to these distributional differences than polyploidy in animal parthenogens. This finding points to the importance of controlling for hybrid ancestry, which is very common in asexual polyploids, when evaluating the ecological consequences of polyploidy. Given the common co-occurrence of hybridization, polyploidy, and asexuality, it is perhaps not surprising that the extent to which polyploidy is likely to explain different distributions of sexual and asexual taxa is controversial and remains unclear (Mable, 2004; Lundmark and Saura, 2006; Vrijenhoek and Parker, 2009; Maniatsi et al., 2011; King et al., 2012).

$P$ availability and the predicted distribution of asexual polyploids All else being equal, if polyploid animal taxa show greater sensitivity to environmental $\mathrm{P}$, there should be predictable associations between the distribution of diploid and polyploid lineages and the availability of P. In particular, diploids should tend to be found in habitats in which $\mathrm{P}$ availability is low relative to habitats in which polyploid counterparts are common. If we apply these predictions to the distribution of sexual diploids vs. asexual polyploids, we would expect that asexual polyploids would occur at high frequency relative to diploid sexual relatives in relatively P-rich habitats, especially given the growing body of evidence for a growth rate advantage of organisms with higher allocation to rRNA (growth rate hypothesis, Elser et al., 1996) in environments where P is not limiting (Elser et al., 2006). In contrast, diploid asexuals should not be distributed differently than diploid sexuals with regard to $\mathrm{P}$ availability. Across asexual animal taxa, the higher the ploidy level, the more restricted their distribution should be with regard to $\mathrm{P}$ availability.

Similar arguments have been made with respect to the evolution of ploidy level in unicellular organisms (Lewis, 1985), heterochromatic content (Cavalier-Smith, 2005) and genome size (Elser et al., 2000a; Hessen et al., 2008, 2010). Of most direct relevance to our hypothesis is empirical evidence from algae and yeast suggesting that haploids are better competitors than diploids in low-P environments (Adams and Hansche, 1974; Destombe et al., 1993; Zeyl, 2004; but see Mable, 2001). Several well-established broad-scale biogeographical patterns are consistent with hypotheses relating nuclear DNA content to dietary P availability, though whether these patterns are directly linked to $\mathrm{P}$ limitation remains untested. For example, Knight and Ackerly (2002), found that angiosperm taxa with relatively high nuclear DNA content were more limited by temperature extremes and low annual precipitation than taxa with lower nuclear DNA content. Gregory and Hebert (1999) argued that a similar association between organisms with larger total cellular DNA content (that is, both higher ploidy and larger genomes) and higher latitude and/or altitude provides convincing support for the hypothesis that natural selection can act directly upon nuclear DNA content.

The well-established pattern of greater prevalence of polyploids at higher latitudes and altitudes could be linked to corresponding gradients in nutrient availability. Temperate and tropical soils vary substantially in age and fertility, but the warm, high-precipitation environments in the tropics tend to have soils that are older, more highly leached, and less fertile than soils at higher latitudes (Chadwick et al., 1999). Several studies have found broad-scale increases in plant leaf nitrogen $(\mathrm{N}), \mathrm{P}$ and $\mathrm{P}: \mathrm{N}$ ratio at higher latitudes (Reich and Oleksyn, 2004; McGroddy et al., 2004; Kerkhoff et al., 2005) that reflect these changes in soil fertility, suggesting that $\mathrm{P}$ constraints in particular may be less important at the base of food webs at higher latitudes. Similar altitudinal trends in leaf nutrient concentrations have also been documented (Körner, 1989).

Given that P limitation for autotrophs appears to be prevalent in marine, freshwater, and terrestrial systems, selective constraints on $\mathrm{P}$-demanding traits may be widespread. However, global patterns of $\mathrm{P}$ limitation are still poorly described, especially for animals, and a comprehensive survey of available data suggested that latitude may be a poor predictor of $\mathrm{P}$ limitation (Elser et al., 2007). It is clear that detailed studies on trophic interactions and the extent of nutrient limitation in natural populations are needed before nutrient availability can be directly implicated in the distribution of sexual vs. asexual animal taxa and the maintenance of sex.

\section{CASE STUDY: BODY COMPOSITION IN SEXUAL DIPLOID VS.} ASEXUAL POLYPLOID FRESHWATER SNAILS

One potential model system for studying relationships among $\mathrm{P}$ limitation, animal polyploidy, and sex is the New Zealand freshwater snail Potamopyrgus antipodarum. This species is characterized by obligately sexual and obligately asexual individuals that co-occur in lakes across New Zealand (Winterbourn, 1970; Lively, 1987, 1992). Like many asexual animals (Suomalainen et al., 1987; Otto and 
Whitton, 2000), asexual P. antipodarum are polyploid (triploid $(3 \times)$ and $>3 \times$ ) and sexuals are diploid (Wallace, 1992). One exceptional characteristic of this system is that there is substantial across-lake variation in the relative frequency of sexual and asexual snails (Lively and Jokela, 2002), and in the relative frequency of triploid and $>3 \times$ asexuals (Neiman et al., 2011). In addition, asexual lineages are the product of multiple independent transitions from sexual P. antipodarum (Dybdahl and Lively, 1995; Neiman and Lively, 2004) and $>3 \times$ asexuals have also evolved multiple times (apparently from triploid ancestors, Neiman et al., 2011). The repeated transitions to polyploid asexuality from sexual diploid $P$. antipodarum and the multiple origins of ploidy variation within asexual P. antipodarum make it possible to disentangle the effects of sex and ploidy on traits such as resource demands while controlling for potential confounding factors of genetic background.

For P-limitation to pose a disadvantage for polyploids, higher ploidy must be associated with higher $\mathrm{P}$ concentrations in whole organisms and asexual polyploids must be more sensitive to $\mathrm{P}$ limitation than sexual diploids. We have evidence that both conditions are met in $P$. antipodarum. First, triploid asexuals were found to have higher body $\mathrm{P}$ content than sexual diploids (Neiman et al., 2009). As expected, the higher $P$ content in triploids was explained by higher $(\sim 50 \%)$ per-mass amounts of DNA and RNA relative to diploids (Neiman et al., 2009). Also, significant differences in $\mathrm{P}$ content among lineages were mostly explained by variation in RNA content, and nucleic acids comprised a majority of the somatic $\mathrm{P}$ content (mean \pm s.e.: $\mathrm{RNA}=46.0 \% \pm 2.2 \%$; DNA $=19.8 \% \pm 1.2 \%$ ). Subsequent to the publication of our initial comparison (Neiman et al., 2009), we learned that one (then unknown) $>3 \times$ lineage had been included in this study. As expected from a direct link between ploidy level and bodily $\mathrm{P}$ content, this lineage had the highest mean $\mathrm{P}$ content of all lineages included in this study and had $\sim 2 \times$ the $\mathrm{P}$ of the sexual diploids.

Although no study has compared P limitation between diploid and polyploid $P$. antipodarum, there is evidence that polyploid $P$. antipodarum are sensitive to $\mathrm{P}$ limitation. On a P-limited diet, triploid $P$. antipodarum exhibit lower growth rates, later reproduction, and smaller broods relative to snails fed a diet high in $\mathrm{P}$ (Tibbets et al., 2010). In addition, growth of $>3 \times P$. antipodarum is more sensitive to $\mathrm{P}$ limitation than growth of triploids (Neiman, Kay, Krist, in review).

These data are the first to show differences in elemental composition between sexual and asexual animals, and satisfy critical assumptions of the hypothesis that $\mathrm{P}$ limitation could pose a cost to polyploidy in $P$. antipodarum. They set the stage for the possibility that sexual diploid snails could make up at least some of the cost of sex where environmental $\mathrm{P}$ availability is scarce.

\section{EMPIRICAL APPROACH}

There are not yet sufficient data to directly test whether P constraints on polyploidy contribute broadly to the persistence of sex in natural populations. Relevant work toward this end would be based on comparisons between sexual and asexual animal taxa of varying ploidy. This would include (1) estimation of DNA and RNA contributions to biomass (Neiman et al., 2009), (2) mesocosm experiments estimating the sensitivity of growth rate or other fitness correlates to dietary $\mathrm{P}$ availability, (3) lab and field experiments examining whether $\mathrm{P}$ availability mediates outcomes of competition between sexual vs. asexual taxa and/or taxa of different ploidy, (4) observational and experimental studies examining whether asexual polyploids become more prevalent than diploid relatives in communities under P-rich conditions and (5) laboratory experiments and genetic analyses comparing traits relevant to nutrient demand (for example, genome size, cell size, P-demand, rRNA gene copy number, gene expression patterns, $\mathrm{P}$, and RNA content) in populations from environments with a range of $\mathrm{P}$ availability and in established vs. recently derived polyploid lineages. This last approach could provide insight into whether there is local adaptation and acclimation to P availability (Elser et al., 2000a, 2006; DeMott and Pape, 2005; Jeyasingh and Weider, 2007; Jeyasingh et al., 2009) and whether polyploids change predictably over evolutionary time (Leitch and Bennett, 2004). The answers to these questions will provide important steps towards understanding whether and how evolution is mediated by the interaction between $\mathrm{P}$ requirements and $\mathrm{P}$ availability. In general, a better understanding of genetic, biochemical, and physiological differences between polyploids and diploids as well as sexual vs. asexual taxa should help identify differences in sensitivity to resource availability, which may in turn reveal key ecological conditions mediating the success of sex.

We suggest that empirical work on the ploidy-sex-phosphorus connection should focus on invertebrate animals. This hypothesis is likely more relevant for invertebrate biology than for vertebrate or plant biology because nucleic acids contribute a much higher fraction of organism $\mathrm{P}$ in invertebrates than in vertebrates, which contain a substantial fraction of $\mathrm{P}$ in bones (Sterner and Elser, 2002), and in plants, which can store large amounts of $\mathrm{P}$ in vacuoles (Matzek and Vitousek, 2009). These alternative $P$ pools could obscure relationships between $\mathrm{P}$ limitation and allocation to nucleic acids (Hessen et al., 2010).

Disentangling the role of polyploidy and nutrient limitation in the distribution and maintenance of sex requires study systems that allow phylogenetically independent comparisons of taxa that vary in ploidy, but not sex, and vice versa, and are otherwise very similar. In other words, taxa are needed that vary in mating system and ploidy such that mating systems can be compared and ploidy level held constant and ploidy can be compared while mating system is held constant. While these requirements are quite simple, few taxa are likely to provide an ideal basis for comparison. For example, pseudogamous (sperm dependent) asexual animals, which are common (Beukeboom and Vrijenhoek, 1998), are of limited use for addressing questions involving differential distribution of taxa that differ in ploidy level because their distribution is constrained by the distribution of the sexual taxon(a) from which they parasitize sperm. Hybrid asexual taxa are also less than ideal because their asexual status is confounded with hybrid ancestry. Examples of systems that seem to be ideally suited based on criteria outlined above are rare, but include many weevil taxa $(2 \times$ sexuals, asexual $2-5 \times$; Suomalainen, 1969; Tomiuk and Loeschcke, 1992) and the brine shrimp Artemia (sexual $2 \times$, asexual 2-4× ; Maniatsi et al., 2011). Other systems that allow at least partial decoupling of sex and ploidy level include Potamopyrgus antipodarum (sexual $2 \times$, asexual 3-4×; Neiman et al., 2011) and the cockroach genus Pycnoscelus $(2 \times$ sexuals, $2 \times$ and $3 \times$ asexuals; Gade and Parker, 1997). Thorough surveys of many additional polyploid taxa that vary in mating system can be found in Suomalainen et al. (1987); Otto and Whitton (2000); Lundmark and Saura (2006); and Neiman and Schwander (2011).

\section{CONCLUSIONS}

The potential for higher sensitivity to $\mathrm{P}$ limitation in polyploids may constitute an ecological cost often associated with asexuality that could help to explain some of the distributional differences between sexual diploid and asexual polyploid animal taxa. This hypothesis for 
the maintenance of sex is novel in suggesting that when polyploidy is costly, it may at times counter the cost of sex, and also in postulating a potential advantage for diploid sexuals when resources are limited.

Multiple mechanisms may often contribute to the persistence of sex (West et al., 1999; recently reviewed in Zimmer, 2009, Meirmans et al., 2012). This means that any disadvantages conferred by nutrient constraints upon polyploid asexuals may facilitate the maintenance of sex, even if nutrient costs are too low to favor sex when considered alone. In particular, we suggest that nutrient constraints on polyploid asexuals will influence the importance of other mechanisms favoring sex across resource gradients. For example, benefits obtained from producing genetically variable offspring may more commonly provide a net advantage for sexuals over polyploid asexuals under P-limited conditions. Thus, resource-related disadvantages of polyploidy should be viewed as complementary to other mechanisms that may favor sexual reproduction.

\section{DATA ARCHIVING}

There were no data to deposit.

\section{CONFLICT OF INTEREST}

The authors declare no conflict of interest.

\section{ACKNOWLEDGEMENTS}

We thank P Jeyasingh, S Keller, M Mayry, D Sloan, D Sowell, D Taylor, $\mathrm{K}$ Theisen, $\mathrm{P}$ Tiffin and $\mathrm{S}$ Wenner for discussion of the ideas presented in the MS, and P Jeyasingh, B Koskella, T Linksvayer, J Logsdon, A Shurko, D Taylor, $\mathrm{K}$ Theisen, $\mathrm{P}$ Tiffin and S Wenner for comments on an earlier version of the manuscript. Funding for M Neiman comes from the Research Council of Norway (Project No. 196468/V40) and the National Science Foundation MCB \#1122176.

Adams J, Hansche PE (1974). Population studies in microorganisms I. Evolution of diploidy in Saccharomyces cerevisiae. Genetics 76: 327-338.

Adams KL (2007). Evolution of duplicate gene expression in polyploid and hybrid plants. J Hered 98: 136-141.

Adams KL, Wendel JF (2005). Novel patterns of gene expression in polyploid plants. Trends Genet 21: 539-543.

Adolfsson S, Michalakis Y, Paczesniak D, Bode SNS, Butlin RK, Lamatsch DK et al. (2010). Evaluation of elevated ploidy and asexual reproduction as alternative explanations for geographic parthenogenesis in Eucypris virens ostracods. Evolution 64: 986-997.

Albertin W, Marullo P (2012). Polyploidy in fungi: evolution after whole-genome duplication. Proc Roy Soc Lond B 279: 2497-2509.

Albertin W, Balliau T, Brabant P, Chèvre A-M, Eber F, Malosse $C$ et al. (2006). Numerous and rapid nonstochastic modifications of gene products in newly synthesized Brassica napus allotetraploids. Genetics 173: 1101-1113.

Auger DL, Gray AD, Ream TS, Kato A, Coe EH, Birchler JA (2005). Nonadditive gene expression in diploid and triploid hybrids of maize. Genetics 169. 389-397.

Bachmann K, Bogart JP (1975). Comparative cytochemical measurements in the diploidtetraploid species pair of hylid frogs Hyla chrysocselis and $\mathrm{H}$. versicolor. Cytogenet $\mathrm{Cell}$ Genet 15: 186-194.

Balao F, Herrera J, Talavera S (2011). Phenotypic consequences of polyploidy and genome size at the microevolutionary scale: a multivariate morphological approach. New Phyto 192: 256-265.

Beaton MJ, Hebert PDN (1988). Geographical parthenogenesis and polyploidy in Daphnia pulex. Am Nat 132: 837-845.

Beck JB, Windham MD, Pryer KM (2011). Do asexual polyploid lineages lead short evolutionary lives? A case-study from the fern genus. Astrolepis. Evolution 65: 3217-3229.

Bell G (1982). The Masterpiece of Nature. Croon Helm: London.

Ben-Ami F, Heller J (2007). Temporal patterns of geographic parthenogenesis in a freshwater snail. Biol J Linn Soc 91: 711-718.

Benfey TJ (1999). The physiology and behavior of triploid fishes. Rev Fish Sci 7: 39-67.

Beukeboom LW, Vrijenhoek RC (1998). Evolutionary genetics and ecology of spermdependent parthenogenesis. J Evol Biol 11: 755-782.

Bierzychudek P (1985). Patterns in plant parthenogenesis. Experientia 41: 1255-1264.
Birchler JA, Bhadra U, Pal Bhadra M, Auger DL (2001). Dosage-dependent gene regulation in multicellular eukaryotes: implications for dosage compensation, aneuploid syndromes, and quantitative traits. Dev Biol 234: 275-288.

Buggs RJA, Pannell JR (2007). Ecological differentiation and diploid superiority across a moving ploidy contact zone. Evolution 61: 125-140.

Buggs RJA, Chamala S, Wu W, Tate JA, Schnable PS, Soltis DE et al. (2012). Rapid, repeated, and clustered loss of duplicate genes in allopolyploid plant populations of independent origin. Curr Biol 22: 248-252.

Butlin RK, Schön I, Martens K (1999). Origin, age and diversity of clones. J Evol Biol 12: 1020-1022.

Cavalier-Smith T (1978). Nuclear volume control by nucleoskeletal DNA, selection for cell volume and cell growth rate, and the solution of the DNA C-value paradox. J Cell Sci 34: 247-278.

Cavalier-Smith T (2005). Economy, speed and size matter: evolutionary forces driving genome miniaturization and expansion. Ann Bot 95: 147-175.

Chadwick OA, Derry LA, Vitousek PM, Huebert BJ, Hedin LO (1999). Changing sources of nutrients during four million years of ecosystem development. Nature 397: 491-497.

Chase JM, Leibold MA (2003). Ecological Niches: Linking Classical and Contemporary Approaches. University of Chicago Press: Chicago.

Church SA, Spaulding EJ (2009). Gene expression in a wild autopolyploid sunflower series. J Hered 100: 491-495.

Comai L (2005). The advantages and disadvantages of being polyploid. Nat Rev Genet 6 : 836-846.

DeMott WR, Pape BJ (2005). Stoichiometry in an ecological context: testing for links between Daphnia P-content, growth rate and habitat preference. Oecologia 142: 20-27.

Destombe C, Godin J, Nocher M, Richerd S, Valero M (1993). Differences between haploid and diploid isomorphic phases of Gracilaria verrucosa (Rhodophyta: Gigartinales) exposed to artificial environmental conditions. Hydrobiologia 260/261: 131-137.

Doncaster CP, Pound GE, Cox SJ (2000). The ecological cost of sex. Nature 404: $281-285$.

Dybdahl MF, Lively CM (1995). Diverse, endemic and polyphyletic clones in mixed populations of a freshwater snail. J Evol Biol 8: 385-398.

Eilam T, Anikster Y, Millet E, Manisterski J, Feldman M (2010). Genome size in diploids, allopolyploids, and autopolyploids of Mediterranean Triticeae. J Bot 341380: 12.

Elser JJ, Hamilton A (2007). Stoichiometry and the new biology - the future is now. PLoS Biol 5: 1403-1405

Elser JJ, Acharya K, Kyle M (2003). Growth rate-stoichiometry couplings in diverse biota. Ecol Lett 6: 936-943.

Elser JJ, Acquisti C, Kumar S (2011). Stoichiogenomics: the evolutionary ecology of macromolecular elemental composition. Trends Ecol Evol 26: 38-44.

Elser JJ, Sterner RW, Gorokhova E (2000b). Biological stoichiometry from genes to ecosystems. Ecol Lett 3: 540-550.

Elser JJ, Dobberfuhl DR, McKay NA, Schampel JH (1996). Organism size, life history, and N:P stoichiometry. Bioscience 46: 674-684.

Elser JJ, O'Brien WJ, Dobberfuhl DR, Dowling TE (2000a). The evolution of ecosystem processes: growth rate and elemental stoichiometry of a key herbivore in temperate and arctic habitats. J Evol Biol 13: 845-853.

Elser JJ, Watts T, Bitler B, Markow TA (2006). Ontogenetic coupling of growth rate with RNA and P contents in five species of Drosophila. Func Ecol 20: 846-856.

Elser JJ, Bracken MES, Cleland EE, Gruner DS, Harpole WS, Hillebrand H et al. (2007). Global analysis of nitrogen and phosphorus limitation of primary producers in freshwater, marine and terrestrial ecosystems. Ecol Lett 12: 1135-1142.

Fagan WF, Denno RF (2004). Stoichiometry of actual vs. potential predator-prey interactions: insights into nitrogen limitation for arthropod predators. Ecol Lett 7 : 876-883.

Fankhauser G (1945). The effects of changes in chromosome number on amphibian development. $Q$ Rev Biol 20: 20-78.

Flagel LE, Wendel JF (2009). Gene duplication and evolutionary novelty in plants. New Phytol 183: 557-564.

Frantz A, Plantegenest M, Simon J-C (2006). Temporal habitat variability and the maintenance of sex in host populations of the pea aphid. Proc Roy Soc Lond B 273: 2887-2891.

Frost PC, Benstead JP, Cross WF, Hillebrand H, Larson JH, Xenopoulos MA et al. (2006). Threshold elemental ratios of carbon and phosphorus in aquatic consumers. Ecol Lett 9: 774-779.

Gade B, Parker Jr ED (1997). The effect of life cycle and genotype on dessication tolerance in the colonizing parthenogenetic cockroach Pynoscelus surinamensis and its sexual ancestor P. indicus. J Evol Biol 10: 479-493.

Galitski T, Saldanha AJ, Styles CA, Lander ES, Fink GR (1999). Ploidy regulation of gene expression. Science 285: 251-254.

Gerstein AC, Otto SP (2009). Ploidy and the causes of genomic evolution. J Hered 100: 571-581.

Gerstein AC, Chung H-JE, Grant A, Otto SP (2006). Genomic convergence towards diploidy in Saccharomyces cerevisiae. PLoS Genet 2: 1396-1401.

Ghiselin MT (1974). The Economy of Nature and the Evolution of Sex. University of California Press: Berkeley.

Gillooly JF, Allen AP, Brown JH, Elser JJ, del Rio CM, Savage VM et al. (2005). The metabolic basis of whole-organism RNA and phosphorus content. Proc Natl Acad Sci USA 102: $11923-11927$

Glesener RR, Tilman D (1978). Sexuality and the components of environmental uncertainty: clues from geographic parthenogenesis in terrestrial animals. Am Nat 112: $259-273$ 
Gregory TR (2001). Coincidence, coevolution, or causation? DNA content, cell size, and the C- value enigma. Biol Rev 76: 65-101.

Gregory TR (2005). The C-value enigma in plants and animals: a review of parallels and an appeal for partnership. Ann Bot 95: 133-146.

Gregory TR, Hebert PDN (1999). The modulation of DNA content: proximate causes and ultimate consequences. Genome Res 9: 317-324.

Grover JP (1997). Resource Competition. Chapman and Hall: New York.

Guo M, Davis D, Birchler JA (1996). Dosage effects on gene expression in a maize ploidy series. Genetics 142: 1349-1355.

Hegarty MJ, Hiscock SJ (2007). Polyploidy: doubling up for evolutionary success. Curr Biol 17: R929-R929.

Hegarty MJ, Hiscock SJ (2008). Genomic clues to the evolutionary success of polyploid plants. Curr Biol 18: R435-R444.

Hessen D, Ventura M, Elser JJ (2008). Do phosphorus requirements for RNA limit genome size in crustacean zooplankton? Genome 51: 685-691.

Hessen DO, Jeyasingh PD, Neiman M, Weider LJ (2010). Genome streamlining and the elemental costs of growth. Trends Ecol Evol 25: 75-80.

Hörandl E (2006). The complex causality of geographical parthenogenesis. New Phytol 171: 525-538.

Jensen LH, Enghoff H, Frydenberg J, Parker Jr ED (2002). Genetic diversity and the phylogeography of parthenogenesis: comparing bisexual and thelytokous populations of Nemasoma varicorne (Diplopoda: Nemasomatidae) in Denmark. Hereditas 136 184-194.

Jeyasingh PD, Weider LJ (2007). Fundamental links between genes and elements: Evolutionary implications of ecological stoichiometry. $\mathrm{Mol}$ Ecol 16: 4649-4661.

Jeyasingh PD, Weider LJ, Sterner RW (2009). Genetically-based trade-offs in response to stoichiometric food quality influence competition in a keystone aquatic herbivore. Ecol Lett 12: 1229-1237.

Kay AD, Ashton IW, Gorokhova E, Kerkhoff AJ, Liess A, Litchman E (2005). Toward a stoichiometric framework for evolutionary biology. Oikos 109: 6-17.

Kearney M (2005). Hybridization, glaciation, and geographical parthenogenesis. Trends Ecol Evol 20: 495-502.

Kerkhoff AJ, Enquist BJ, Elser JJ, Fagan WF (2005). Plant allometry, stoichiometry and the temperature-dependence of primary productivity. Global Ecol Biogeograph 14 585-598.

King KC, Seppälä O, Neiman M (2012). Is more better? Polyploidy and parasite resistance. Biol Lett 8: 598-600.

Knight CA, Ackerly DD (2002). Variation in nuclear DNA content across environmental gradients: a quantile regression analysis. Ecol Lett 5: 66-76.

Körner C (1989). The nutritional status of plants from high altitudes - a worldwide comparison. Oecologia 81: 379-391.

Law JH, Crespi BJ (2002). The evolution of geographic parthenogenesis in Timema walking sticks. Mol Ecol 11: 1471-1489.

Leitch IJ, Bennett M (2004). Genome downsizing in polyploid plants. Biol J Linn Soc 82 651-663.

Levin DA (1975). Pest pressure and recombination systems in plants. Am Nat 109 437-451.

Levin DA (1983). Polyploidy and novelty in flowering plants. Am Nat 122: 1-25.

Lewis Jr WM (1985). Nutrient scarcity as an evolutionary cause of haploidy. Am Nat 125 692-701.

Lively CM (1987). Evidence from a New Zealand snail for the maintenance of sex by parasitism. Nature 328: 519-521.

Lively CM (1992). Parthenogenesis in a freshwater snail: reproductive assurance versus parasitic release. Evolution 46: 907-913.

Lively CM, Jokela J (2002). Temporal and spatial distributions of parasites and sex in a freshwater snail. Evol Ecol Res 4: 219-226.

Lundmark M, Saura A (2006). Asexuality alone does not explain the success of clonalforms in insects with geographical parthenogenesis. Hereditas 143: 23-32.

Lynch M (1984). Destabilizing hybridization, general-purpose genotypes, and geographica parthenogenesis. Q Rev Biol 59: 257-290.

Mable BK (2001). Ploidy evolution in the yeast Saccharomyces cerevisiae: a test of the nutrient limitation hypothesis. J Evol Biol 14: 157-170.

Mable BK (2004). 'Why polyploidy is rarer in animals than in plants:' myths and mechanisms. Biol J Linn Soc 82: 453-466.

Mable BK, Otto SP (1998). The evolution of life cycles with diploid and haploid phases. Bioessays 20: 453-462.

Mable BK, Alexandrou MA, Taylor MI (2011). Genome duplication in amphibians and fish an extended synthesis. J Zool 284: 151-182.

MacArthur R (1972). Geographical Ecology. Princeton University Press: Princeton.

Maniatsi S, Baxevanis AD, Kappas I, Deligiannidis P, Triantafyllidis A, Papakostas S, Bougiouklis D, Abatzopoulos TJ (2011). Is polyploidy a perservering accident or an adaptive evolutionary pattern? The case of the brine shrimp Artemia. Mol Phylogenet Evol 58: 353-364.

Martins MJF, Vandekerkhove J, Namiotko T (2008). Environmental stability and the distribution of the sexes: insights from life history experiments with the geographic parthenogen Eucypris virens (Crustacea: Ostracoda). Oikos 117: 829-836.

Matzek V, Vitousek PM (2009). N:P stoichiometry and protein:RNA ratios in vascular plants: an evaluation of the growth-rate hypothesis. Ecol Lett 12: 765-771.

Maynard Smith J (1978). The Evolution of Sex. Cambridge University Press: London.

Mayrose I, Zhan SH, Rothfels CJ, Magnuson-Ford K, Barker MS, Rieseberg LH et al. (2011). Recently formed polyploid plants diversity at lower rates. Science 333: 1257.
McGroddy ME, Daufresne T, Hedin LO (2004). Scaling of C:N:P stoichiometry in forests worldwide: implications of terrestrial redfield-type ratios. Ecology 85: 2390-2401.

Meirmans S, Neiman M (2006). Methodologies for testing a pluralist idea for the maintenance of sex. Biol J Linn Soc 89: 605-613.

Meirmans S, Meirmans PG, Kirkendall LR (2012). The costs of sex: facing real-world complexities. Q Rev Bio/ 87: 19-40.

Moe JS (2005). Recent advances in ecological stoichiometry: insights for population and community ecology. Oikos 109: 29-39.

Morehouse NI, Nakazawa T, Booher CM, Jeyasingh PD, Hall MD (2010). Sex in a materia world: Why the study of sexual reproduction and sex-specific traits should become more nutritionally-explicit. Oikos 119: 766-778.

Murray BG, De Lange PJ, Ferguson AR (2005). Nuclear DNA variation, chromosome numbers and polyploidy in the endemic and indigenous grass flora of New Zealand. Ann Bot 96: 1293-1305

Neiman M, Lively CM (2004). Pleistocene glaciation is implicated in the phylogeographical structure of Potamopyrgus antipodarum, a New Zealand snail. $\mathrm{Mol}$ Ecol 13: 3085-3098.

Neiman M, Schwander T (2011). Using parthenogenetic lineages to identify advantages of sex. Evol Biol 38: 115.

Neiman M, Theisen K, Mayry ME, Kay AD (2009). Can phosphorus limitation contribute to the maintenance of sex? A test of a key assumption. J Evol Biol 22 1359-1363.

Neiman M, Paczesniak D, Soper DM, Baldwin AT, Hehman G (2011). Wide variation in ploidy level and genome size in a New Zealand freshwater snail with coexisting sexua and asexual lineages. Evolution 65: 3202-3216.

Ng DW-K, Zhang C, Miller M, Shen Z, Briggs SP, Chen ZJ (2012). Proteomic divergence in Arabidopsis autopolyploids and allopolyploids and their progenitors. Heredity 108 419-430.

Ohno S (1970). Evolution by Gene Duplication. Springer-Verlag: Berlin.

Otto SP (2007). The evolutionary consequences of polyploidy. Cell 131: 452-462.

Otto SP (2009). The evolutionary enigma of sex. Am Nat 174: S1-S14.

Otto SP, Gerstein AC (2009). Primer: the evolution of haploidy and diploidy. Curr Biol 18 R1121-R1124.

Otto SP, Whitton J (2000). Polyploid incidence and evolution. Ann Rev Genet 34 401-437.

Ozkan H, Tuna M, Arumuganathan K (2003). Nonadditive changes in genome size during allopolyploidization in the wheat (Aegilops-Triticum) group. J Hered 94 260-264.

Parisod C, Holderegger R, Brochmann C (2010). Evolutionary consequences of autopolyploidy. New Phytol 186: 5-17.

Pavelka N, Rancati G, Zhu J, Bradford WD, Saraf A, Florens L et al. (2010). Aneuploidy confers quantitative proteome changes and phenotypic variation in budding yeast. Nature 468: 321-325

Pellicer J, Garcia S, Canela MÁ, Garnatje T, Korobkov AA, Twibell JD et al. (2010). Genome size dynamics in Artemisia L. (Asteraceae): following the track of polyploidy. Plant Biol 12: 820-830

Pignatta D, Dilkes BP, Yoo S-Y, Henry IM, Madlung A, Doerge RW et al. (2010). Differential sensitivity of the Arabidopsis thaliana transcriptome and enhancers to the effects of genome doubling. New Phytol 186: 194-206.

Ramsey J (2011). Polyploidy and ecological adaptation in wild yarrow. Proc Natl Acad Sci USA 108: 7096-7101.

Ramsey J, Schemske DW (2002). Neopolyploidy in flowering plants. Ann Rev Ecol Syst 33: 589-639.

Raubenheimer D, Simpson SJ, Mayntz D (2009). Nutrition, ecology and nutritional ecology: toward an integrated framework. Func Ecol 23: 4-16.

Reich PB, Oleksyn J (2004). Global patterns of plant leaf $N$ and $P$ in relation to temperature and latitude. Proc Natl Acad Sci USA 101: 11001-11006.

Scheu S, Drossel B (2007). Sexual reproduction prevails in a world of structured resources in short supply. Proc R Soc B Lon 274: 1225-1231.

Shimizu Y, Urabe J (2008). Regulation of phosphorus stoichiometry and growth rate of consumers: theoretical and experimental analyses with Daphnia. Oecologia 155: 21-31.

Simpson SJ, Raubenheimer D (2012). Nature of Nutrition: A Unifying Framework from Animal Adaptation to Human Obesity. Princeton University Press: Princeton.

Soltis DE, Buggs RJA, Doyle JJ, Soltis PS (2010). What we still don't know about polyploidy. Taxon 59: 1387-1403.

Song Y, Drossel B, Scheu S (2011). Tangled Bank dismissed too early. Oikos 120: $1601-1607$

Stebbins GL (1938). Cytological characteristics associated with the different growth habits in dicotyledons. Am J Bot 25: 180-198.

Stelzer RS, Lamberti GA (2002). Ecological stoichiometry in running waters: periphyton chemical composition and snail growth. Ecology 83: 1039-1051.

Stenberg P, Lundmark M, Knutelski S, Saura A (2003). Evolution of clonality and polyploidy in a weevil system. Mol Biol Evol 20: 1626-1632.

Sterner RW, Elser JJ (2002). Ecological Stoichiometry: The Biology of Elements from Molecules to the Biosphere. Princeton University Press: Princeton.

Stupar RM, Bhaskar PB, Yandell BS, Rensink WA, Hart AL, Ouyang S et al. (2007). Phenotypic and transcriptomic changes associated with potato autopolyploidization. Genetics 176: 2055-2067.

Suomalainen E (1950). Parthenogenesis in animals. Adv Genet 3: 193-259.

Suomalainen E (1969). Evolution in parthenogenetic Curculionidae. Evol Biol 3 261-296. 
Suomalainen E, Saura A, Lokki J (1987). Polyploidy in association with parthenogenesis. In: Suomalainen E, Saura A, Lokki J (eds) Cytology and Evolution in Parthenogenesis. CRC Press: Boca Raton, Pp 71-112.

te Beest M, Le Roux JJ, Richardson DM, Brysting AK, Suda J, Kubešová M et al. (2012). The more the better? The role of polyploidy in facilitating plant invasions. Ann Bot 109: $19-45$.

Tibbets TM, Krist AC, Hall Jr RO, Riley LA (2010). Phosphorus-mediated changes in life history traits of the invasive New Zealand mudsnail (Potamopyrgus antipodarum). Oecologia 163: 549-559.

Tilman D (1982). Resource Competition and Community Structure. Princeton University Press: Princeton.

Tomiuk J, Loeschcke V (1992). Evolution of parthenogenesis in the Otiorhynchus scaber complex. Heredity 68: 391-398.

Vandel A (1928). La parthenogenese geographique. Contribution a l'etude biologique et Cytologique de la parthenogenese naturelle. Bull Biol Fr Belg 62: 164-281.

Vandel A (1940). La parthenogenese geographique. IV. Polyploidie et distribution geographique. Bull Biol Fr Belg 74: 94-100.
Vrijenhoek RC, Parker Jr ED (2009). Geographical parthenogenesis: general purpose genotypes and frozen niche variation. In: Schön KM, van Dijk P (eds) Lost Sex: The Evolutionary Biology of Parthenogenesis. Springer: Dordrecht, Pp 99-132.

Wallace C (1992). Parthenogenesis, sex, and chromosomes in Potamopyrgus. J Moll Stud 58: 93-107.

Wang J, Tian L, Lee H-S, Wei NE, Jiang H, Watson B et al. (2006). Genomewide nonadditive gene regulation in Arabidopsis allotetraploids. Genetics 172: 507-517.

Wendel JF (2000). Genome evolution in polyploids. Plant Mol Biol 42: 225-249.

West SA, Lively CM, Read AF (1999). A pluralist approach to sex and recombination. J Evol Biol 12: 1003-1012.

Winterbourn MJ (1970). Population studies on the New Zealand freshwater gastropod Potamopyrgus antipodarum (Gray). Proc Malacolog Soc Lond 39: 139-149.

Young JPW (1981). Sib competition can favour sex in two ways. J Theor Biol 88 : $755-756$.

Zeyl C (2004). Experimental studies of ploidy evolution in yeast. FEMS Microbiol Lett 233: $187-192$

Zimmer C (2009). On the origin of sexual reproduction. Science 324: 1254-1256. 